\title{
BREXIT, PROROGATION AND POPCORN: IMPLICATIONS OF MILLER (No 2) FOR NEW ZEALAND
}

\author{
Dean R Knight*
}

\begin{abstract}
I
In July last year, I headed to the United Kingdom for a few months sabbatical. The plan was to graft away quietly on some research projects. The Law Department at the London School of Economics had kindly provided a quiet office for me to scribble away in. Other than that, I only had a few planned adventures. A couple of conferences and symposia to chew the fat with colleagues about judicial review methodology and fundamental principles of constitutional law. Perhaps, too, a show at the West End - a little bit of theatre to break up those dreamy days of writing.
\end{abstract}

But how wrong I was!

What ensued was an action-packed period of civic drama. It was like Christmas for a constitutional trainspotter like me. As an Antipodean interloper, all I could do was watch the drama unfold, with googly eyes, stuffing my face with popcorn, as the British state was in turmoil and at risk of selfdestructing - I do not think that is an exaggeration. And what a drama. My jaw would drop every morning reading The Guardian over my morning coffee. Bizarre stories of constitutional intrigue almost as fanciful as fact patterns drafted by professors for exams. Scrolling through Twitter on the number one Tottenham Court Road bus would bring another round of astonishment. That would lead to multiple retweets of each crazy development, adorned with the increasingly apt popcorn emoji hence the title of this address.

The main plot twist, as we all know, was the Supreme Court ruling that the prorogation of Parliament was unlawful. ${ }^{1}$ When advising the Queen to prorogue Parliament, the Prime Minister had

* Associate Professor, Faculty of Law and New Zealand Centre for Public Law, Victoria University of Wellington (dean.knight@vuw.ac.nz). This is an edited version of the keynote address to the Government Law - Year in Review conference, New Zealand Centre for Public Law, Victoria University of Wellington (February 2020). Thanks, subject to the usual caveat, to Claudia Geiringer and Thomas Poole for feedback and thanks also to Maisy Bentley for research assistance.

$1 \quad R$ (Miller) v Prime Minister [2019] UKSC 41, [2020] AC 373 [Miller (No 2)]. 
no reasonable justification for suspending the operation of Parliament, for an extended period and at such a crucial time in Brexit's constitutional reordering, when suspension seriously frustrated Parliament's constitutional duty to hold the executive to account. ${ }^{2}$

My task in this address is to throw you into the middle of this British constitutional drama and to try to make sense of the Supreme Court's decision. It is a decision that has polarised public law experts: it has been both celebrated and condemned. ${ }^{3}$ Thus, there is some work to understand the decision in its extraordinary context, explore its implications for Westminster constitutionalism and speculate on what sort of precedent it sets for judicial review of the prerogative. Importantly for this audience, I would like to reflect on the relevance to us, sitting, as we do, over 10,000 miles from the drama in Westminster. In other words, I would like to test the New Zealand "what if?" question. Could a similar meltdown happen here? And, if so, how would our constitutional agents react?

\section{II}

Our story climaxes on 24 September 2019 as the United Kingdom Supreme Court in R (Miller) $v$ Prime Minister (Miller (No 2)) quashes the prorogation of the British Parliament. ${ }^{4}$ But, in many respects, it is a story that began some time earlier. Of course, the Brexit referendum and pathway provide a key arc for this story. However, more important - as I soon realised when I landed in London - was the struggle for dominance between the executive and legislature. It is this fiery battle that cultivated the ground for the prorogation saga. Witness some examples of the bizarre and often constitutionally exceptional hijinks that took place or were seriously suggested. For example, the

2 At [61].

3 For a sample of the competing views see the exchanges between Paul Craig and Martin Loughlin in the Public Law journal: Paul Craig "The Supreme Court, prorogation and constitutional principle" [2020] PL 248; Martin Loughlin "A note on Craig on Miller; Cherry" [2020] PL 278; and Paul Craig "Response to Loughlin's note on Miller; Cherry" [2020] PL 282. See also the celebration of the decision by others, including Thomas Poole "Understanding what makes 'Miller \& Cherry' the most significant judicial statement on the constitution in over 200 years" Prospect Magazine (online ed, London, 25 September 2019); Stephen Sedley "In Court" London Review of Books (online ed, London, 10 October 2019); Nick Barber "Constitutional hardball and justified development of the law" (29 September 2019) Judicial Power Project <www.judicialpower project.org.uk>; and Alison Young "Deftly Guarding the Constitution" (29 September 2019) Judicial Power Project <www.judicialpowerproject.org.uk>. Compare John Finnis The unconstitutionality of the Supreme Court's prorogation judgment (Policy Exchange, 2019); John Finnis The Law of the Constitution before the Court: Supplementary Notes on The unconstitutionality of the Supreme Court's prorogation judgment (Policy Exchange, 2019); Richard Ekins and Stephen Laws "The Supreme Court has done lasting damage to our constitution" Prospect Magazine (online ed, London, 4 October 2019); Richard Ekins Protecting the Constitution (Policy Exchange, 2019); and Martin Loughlin The Case of Prorogation (Policy Exchange, 2019).

4 Miller (No 2), above n 1, at [70]-[71]. 
opposition "seizing control" of the order paper to pass a Bill contrary to the government's wishes. ${ }^{5}$ Suggestions ministers should withhold royal assent from such a Bill. ${ }^{6}$ Suggestions the Prime Minister could, once the Bill was assented to, otherwise disregard the Act's obligations to seek an extension of the Brexit deadline. ${ }^{7}$ Suggestions, too, that the law could be suspended under the Civil Contingencies Act 2004 on the basis of some national emergency. ${ }^{8}$ I could go on and on.

Each of those might provide fodder for a constitutional lecture in their own right. But, here, they provide context for the main event only. A belligerent executive, adamant in the belief of its divine right to rule. An executive dismissive of Parliament and its desire to be a player in the Brexit saga, despite Parliament's own atomisation and inability to speak with a strong voice on Brexit. Boris Johnson's then catchcry summed up the cultural state-of-play: "Let's get Brexit done". It would be done. And the government would do everything possible to neutralise any interference in the achievement of its goal. As an aside, most of those constitutional horrors did not arise in reality. But that might be beside the point. Those exceptional suggestions helped erode any culture of constitutional fidelity and civic virtue. The gloves came off in this battle between her Majesty's government and the people's assembly.

Prorogation did crystallise as the main weapon in the fight. Prorogation suspends the sittings and business of Parliament; in other words, prorogation is Parliament's temporary time out. Erskine May explains prorogation in prerogative terms: "[j]ust as Parliament can commence its deliberations only at the time appointed by the Queen, so it cannot continue them any longer than she pleases." 9 However, in accordance with the cardinal constitutional convention, the monarch prorogues Parliament on advice of the executive. Hence, prorogation is a potential tool of executive government. The idea of prorogation had been floating around for some time as a way to provide some respite from an interfering Commons. As early as April, Professor Finnis floated the idea, perhaps to be timed across the Halloween deadline to ensure a no deal Brexit. ${ }^{10}$

5 Tim Stanley "This wretched and inept Parliament has seized control. No wonder the public are in despair" The Telegraph (online ed, London, 4 September 2019).

6 Robert Craig "Could the Government Advise the Queen to Refuse Royal Assent to a Backbench Bill?" (22 January 2019) UK Constitutional Law Association Blog 〈www.ukconstitutionallaw.org>.

7 James Blitz "Can Boris Johnson bypass the Benn Act?" Financial Times (online ed, London, 28 September 2019).

8 "Could the government deliver Brexit by declaring a national emergency?" New Statesman (online ed, London, 9 September 2019).

9 David Natzler and others (eds) Erskine May Parliamentary Practice: Treatise on the law, privileges, proceedings and usage of Parliament (25th ed, LexisNexis Butterworths, London, 2019) at [8.5].

10 John Finnis "Only one option remains with Brexit - prorogue Parliament and allow us out of the EU with nodeal" The Telegraph (online ed, London, 1 April 2019). 
In the end, prorogation came to pass quite quickly, almost under the radar. We discover, after the fact, that Johnson floated a mid-October Queen's speech to kick off a new parliamentary session soon after he took over as prime minister from Theresa May. His director of legislative affairs, Nikki da Costa, drafted a memorandum in mid-August setting out the timeline for that. ${ }^{11}$ She proposed that Parliament stand prorogued for over five weeks, with some of that time expected to be taken up by party conferences. The Prime Minister scribbled his agreement, along with some pejorative doodles, including his view that there was nothing "shocking" about this prorogation. ${ }^{12}$ On 27 August, there was a brief phone call between Johnson and the Queen but we do not know what was said. ${ }^{13}$ The next day, Jacob Rees-Mogg (Leader of the House of Commons and Lord President of the Council) and two others jetted off to Balmoral. ${ }^{14}$ At a small meeting of the privy council, her Majesty agreed to the Order-in-Council for prorogation: "Approved". 15

Parliament only had a small window to react. In the following week, it moved to pass the European Union (Withdrawal) (No 6) Bill 2019 (the Benn Bill), requiring the Prime Minister to seek an extension from the European Union to avoid a no deal Brexit - then a probable horror scenario - if that prospect arose. ${ }^{16}$ However, the guillotine soon fell on its proceedings.

Late one Monday night, 9 September 2019, the Commons debated the obligation of the Prime Minister to comply with the rule of law, made a humble address to the Queen requiring the government to disclose key worst case scenario modelling reports, approved some essential statutory instruments for Northern Ireland and voted - unsuccessfully - to dissolve for an early election under the processes mandated by the Fixed-term Parliaments Act 2011. ${ }^{17}$ It was a surreal night for those of us watching in the gallery. Then Black Rod summonsed the Members of Parliament to assemble in the Lords and, eventually, they obliged. A handful of us wandered over to witness, mingling with Black Rod and her team in the foyer of the Lords before the gallery was unlocked. Now into the early hours of Tuesday morning, the pomp and ceremony began. Three of her Majesty's commissioners - Baroness Evans,

11 Nikki Da Costa "Ending the Session" (Memorandum, 15 August 2019); and Miller (No 2), above n 1 , at [17].

12 Da Costa, above n 11 (Johnson handwritten notes); and Miller (No 2), above n 1, at [18].

13 At [19].

14 Gordon Rayner and Owen Bennett "How Jacob Rees-Mogg had cover blown during secret trip to ask Queen to prorogue Parliament" The Telegraph (online ed, London, 28 August 2019).

15 Privy Council Orders Approved at the Privy Council held by the Queen at Balmoral on 28th August 2019 (Minutes); and Miller (No 2), above n 1, at [15].

16 European Union (Withdrawal) (No 6) Bill 2019 (passed by the Commons on 4 September 2010), enacted as the European Union (Withdrawal) (No 2) Act 2019.

17 (9 September 2019) 664 GBPD HC 519-646; and House of Commons Votes and Proceedings (No 341, 9 September 2019). 
Lord Fowler and Lord Hope - presided from the woolsack. ${ }^{18}$ Two others boycotted. Royal assent was signalled to the Parliament Buildings (Restoration and Renewal) Bill 2019, with the usual uttering in Norman French, la Reyne le vault ("the Queen wills it"). ${ }^{19}$ We might return later to the Bill's odd cameo in this saga. Then came a Queen's speech - trumpeting the government's achievements - but I will save you from that. ${ }^{20}$ Before the curtain dropped with the recital of the Letters Patent: "we do, in Her Majesty's name, and in obedience to Her Majesty's Commands, prorogue this Parliament to the 14th day of October, to be then here holden". ${ }^{21}$ And, on her Majesty's command, Parliament closed its doors.

\section{III}

Fast forward to the litigation that soon ensued: judicial review proceedings across the nation.

A star-studded Divisional Court in $R$ (Miller) $v$ Prime Minister ruled the prorogation - a prerogative act - was non-justiciable. ${ }^{22}$ Although the specific question had never arisen before, this was in line with the widespread understanding that prorogation was a no go zone for the courts, especially because it was acutely political and lacked a suitable benchmark for measuring its propriety. Its Scottish counterpart, the Inner House of the Court of Sessions took a different view in Cherry v Advocate General, ${ }^{23}$ reversing the Outer House below. ${ }^{24}$ While the principles of Scottish judicial review are basically the same as those in England and Wales, the Inner House was not as shy as the Divisional Court about weighing in and rejected any argument prorogation was non-justiciable. The request to prorogue was unlawful because it was motivated by an improper purpose, stymying Parliament's oversight of the executive at the critical Brexit juncture. And, for completeness, the Queen's Bench in Northern Ireland, in a third challenge, declined to express a view on the prorogation question for procedural reasons. ${ }^{25}$

So to the Supreme Court. The Court heard the conjoined appeals in Miller and Cherry, with intervention from applicants in McCord v Prime Minister, over three days in the middle of

18 (9 September 2019) 799 GBPD HL 1399 [Royal Commission].

19 (9 September 2019) 799 GBPD HL 1401 [Royal Assent], assenting to the Parliamentary Buildings (Restoration and Renewal) Bill 2019.

20 (9 September 2019) 799 GBPD HL 1401 [Prorogation: Her Majesty's Speech].

21 (9 September 2019) 799 GBPD HL 1404 [Prorogation: Her Majesty's Speech].

$22 R$ (Miller) v Prime Minister [2019] EWHC 2381 (QB), [2019] WLR(D) 511 (Lord Burnett CJ, Sir Terence Etherton MR and Dame Victoria Sharp P).

23 Cherry v Advocate General [2019] CSIH 49, 2019 SCLR 986 (Lord Carloway P, Lord Brodie and Lord Drummond Young).

24 Cherry v Advocate General [2019] CSOH 70, 2019 SLT 1071.

25 McCord v Prime Minister [2019] NIQB 78. 
September. ${ }^{26}$ I probably do not need to paint a picture of the monumental hearing because many of you probably watched bits of it on the live stream. But much popcorn was consumed.

\section{IV}

Let us move to 24 September 2019: judgment day. A wet and dreary day in London, only made brighter by luckily winning a golden ticket to the main courtroom for the delivery of the decision. Lady Hale read out a summary of the Court's decision, jointly penned by her and Lord Reed, reflecting a unanimous decision of all 11 judges. ${ }^{27}$ The announcement of the latter led to the first audible gasp from the audience in the Middlesex Guildhall - me included. ${ }^{28}$

The Court recorded that there were four issues in play: justiciability, standard, breach and remedy. Starting with the question of justiciability, the Court ruled prorogation was justiciable. Another gasp. It rejected several arguments that prorogation was a no go zone. It did not matter that prorogation was politically controversial: much of administrative law deals with matters with "a political hue". ${ }^{29}$ It did not matter that prorogation was something which the executive might be held to account about by Parliament: political accountability does not immunise ministers from legal accountability, especially where, as here, prorogation attenuates political accountability. ${ }^{30}$ And it did not matter that the courts were being called on to assess the actions of the executive under the prerogative in a parliamentary context: the separation of powers did not demand the courts be circumspect in these circumstances especially because, constitutionally, it is the proper function of the courts to ensure that unlawful exercises of prerogative power do not prevent Parliament from conducting its proper functions. Few authorities needed to be cited; the Case of Proclamations and Council of Civil Service Unions $v$ Minister for the Civil Service being the most notable and familiar. ${ }^{31}$

This flowed into the second question about the standard to be applied. Here, the Supreme Court drew a distinction between the scope of the power to prorogue and the exercise of that power. In other words, the power to prorogue was not unfettered. And it was for the courts to determine what those limits were and whether they were breached. Those questions are, the Court said, "by definition

26 For video footage see "R (on the application of Miller) (Appellant) v The Prime Minister (Respondent)" The Supreme Court: Case details <www.supremecourt.uk/cases>.

27 Miller (No 2), above n 1.

28 The gasps from the gallery did not go unnoticed by Lady Hale: see "'There was a gasp in the courtroom' retiring Supreme Court President Lady Hale" (27 December 2019) BBC Sounds <www.bbc.com/news/ video_and_audio>.

$29 \operatorname{Miller}($ No 2), above n 1, at [31].

30 At [33]

31 Case of Proclamations (1611) 12 Co Rep 74, 77 ER 1352 (KB); and Council of Civil Service Unions v Minister for the Civil Service [1985] AC 374 (HL), as cited in Miller (No 2), above n 1, at [32] and [35]. 
questions of law" and "[u]nder the separation of powers ... the function of the courts to determine". ${ }^{32}$ Nods here to the legitimacy of law and judicial competency. I will come back to these points. The Court then explained how this translates into the standard for reviewing lawfulness. The power to prorogue must be defined so it is "compatible" with the principle of "Parliamentary sovereignty" and "Parliamentary accountability". ${ }^{33}$ Crucially, these principles included the obligation of the executive, through various parliamentary mechanisms, to "report, explain and defend its actions" to representatives of the electorate, thereby protecting citizens against the arbitrary exercise of executive power. ${ }^{34}$ Thus it is outside the limits of executive power, whether statutory or prerogative, to impede or frustrate those functions without reasonable justification (something acutely important in this case) or in the absence of clear authorisation in any empowering statute (something irrelevant in this case given it involved non-statutory prerogative power).

In summary, as the Court put it, a decision to prorogue Parliament (or to advise the monarch to prorogue Parliament) will be unlawful if the prorogation has the effect of frustrating or preventing, without reasonable justification, the ability of Parliament to carry out its constitutional functions as a legislature and as the body responsible for the supervision of the executive". ${ }^{35}$ But, tantalisingly, a court will only intervene "if the effect is sufficiently serious to justify such an exceptional course". ${ }^{36}$

Against that benchmark, the Court turned to the evidence and its assessment of whether the standard was breached. Did prorogation interfere with Parliament's accountability functions? "[O]f course, it did" Lady Hale remarked. ${ }^{37}$ It was "not a normal prorogation". ${ }^{38}$ It prevented Parliament from doing its job for "five out of a possible eight weeks" in "quite exceptional" circumstances. ${ }^{39}$ Even if Parliament had paused for party conferences, which was not guaranteed, many of Parliament's accountability processes would continue to tick over if it did so pause.

Was this interference justified? "No reason was given for closing down Parliament for five weeks", Lady Hale said. ${ }^{40}$ Sure, there was some deliberation about when the next Queen's speech reopening Parliament would be. But nothing about the unusual five week length. John Major's

\footnotetext{
$32 \operatorname{Miller}$ (No 2), above $\mathrm{n} 1$, at [36].

33 At [45]-[46].

34 At [46].

35 At [50].

36 At [50].

37 At [56].

38 At [56].

39 At [56]-[57].

40 At [58].
} 
evidence was that 4-6 days was typical and sufficient for preparation for a Queen's speech. Da Costa's memorandum did not address the length or its effect on things like scrutiny of Brexit statutory instruments and the like. Johnson's handwritten annotations characterised sitting in September as a "rigmarole". ${ }^{41}$ So, the Court concluded, on the evidence before it, the government had not offered "any reason - let alone a good reason" for the five week prorogation. ${ }^{42}$ I should pause at this point and note that I do not think that means the advice was proffered without reason per se. The implication was that the government's silence before the Court was an admission that the real reason was politically tactical and potentially nefarious: as the Court put it diplomatically, "the government seeking to promote its own policies". ${ }^{43}$ In other words, any unarticulated reasons did not live up to the constitutional duties of the Prime Minister when so advising her Majesty to prorogue. The Court explained that duty as the obligation to "have regard to all relevant interests, including the interests of Parliament". ${ }^{44}$ Thus the Court ruled the advice to prorogue was unlawful. Another gasp.

The Court then turned to the question of the appropriate remedy. Parliamentary privilege and art 9 of the Bill of Rights 1688 - which protects "a proceeding in Parliament" - was swatted away. Although the ceremony of prorogation takes place in the Lords, it is not a proceeding of Parliament. ${ }^{45}$ It is something imposed on Parliament from outside; in other words, it is not core or essential business of Parliament, especially given it brings the business of Parliament to an end. As the advice to prorogue was unlawful, it followed that the Order-in-Council, "founded on unlawful advice", was also unlawful, null and of no effect. ${ }^{46}$ So too the prorogation ceremony itself: it "was as if the Commissioners had walked into Parliament with a blank piece of paper". ${ }^{47}$ Parliament had not lawfully been prorogued and the Court issued declarations and orders to this effect.

The doors of Parliament reopened the next day. ${ }^{48}$ The Speaker and Clerks moved to correct the record in the journals of both Houses expunging any reference to the prorogation. ${ }^{49} \mathrm{~A}$ small postscript and unfortunate quirk. Remember the Parliamentary Buildings Bill that was given royal assent in the

\author{
41 At [60]. \\ 42 At [61]. \\ 43 At [60]. \\ 44 At [30]. \\ 45 At [68]. \\ 46 At [69]. \\ 47 At [69]. \\ 48 (25 September 2019) 664 GBPD HC 651 [House of Commons]; and (25 September 2019) 799 GBPD HL \\ 1405 [House of Lords]. \\ 49 (25 September 2019) 664 GBPD HC 651 [Speaker's Statement]; and (25 September 2019) 799 GBPD HL \\ 1405 [Lord Speaker's Statement]. The journals of both Houses were rectified to simply record that they were \\ adjourned on 9 September 2019.
}


ceremony of prorogation? As a consequence of the Court's judgment, arrangements were quickly made for royal assent to be signalled again, out of an abundance of caution to avoid any doubt about its validity. ${ }^{50}$ This was unnecessary in my view. I have no doubt the Supreme Court, if asked, would have treated the different parts of the ceremony as being severable and clarified that the unlawfulness did not taint the royal assent. ${ }^{51}$ Indeed, it is regrettable that Parliament was not represented by both Speakers in the judicial review proceedings; the Supreme Court judges were clearly unfamiliar with the minutiae of parliamentary procedure and expert advice on these points might have allowed the point to be squarely addressed by the Court in the relief granted.

What do we make of the decision?

Certainly it was a masterclass in judicial statecraft. We can point to a number of its features: unanimous; crisp and concise; logical, with an air of inevitability; principled. Curious, also, is reasoning without resort to a large swathe of case law and commentary. ${ }^{52}$

But the strength of the reasoning itself?

Some condemn the finding on justiciability. ${ }^{53}$ Critics point to Dicey, Diplock and others previously slating prorogation as non-justiciable and the question being radioactive, political, lacking any legal yardstick and so forth. ${ }^{54}$ These precedents should not be displaced - or the sky will fall, they say. In truth, however, while the ruling is a novel first on the specific point, it was not inconsistent with the direction of travel about justiciability of the prerogative for the last half-century and more. We have seen moves to focus on the substance, not the source, of the power and scepticism about absolute no go zones. ${ }^{55} \mathrm{We}$ have also seen moves to more nuanced review standards to acknowledge

50 (25 September 2019) 664 GBPD HC 651 [Speaker's Statement]; and (8 October 2019) 799 GBPD HL 2073 [Royal Assent].

51 Amongst other things, royal assent and prorogation are usually performed under separate commissions. Paul Craig has also reached a similar view on severability see: Craig "The Supreme Court, prorogation and constitutional principle", above $\mathrm{n} 3$.

52 Compare $R$ (Miller) $v$ Secretary of State for Exiting the European Union [2017] UKSC 5, [2018] AC 61 [Miller (No 1)].

53 See especially Finnis The unconstitutionality of the Supreme Court's prorogation judgment, above n 3; Finnis The Law of the Constitution before the Court, above n 3; Ekins and Laws "The Supreme Court has done lasting damage to our constitution", above n 3; Ekins Protecting the Constitution, above n 3; and Loughlin The Case of Prorogation, above $\mathrm{n} 3$.

54 See for example AV Dicey An Introduction to the Study of the Law of the Constitution (8th ed, Macmillan, London, 1915); and Council of Civil Service Unions, above n 31, at 412 per Lord Diplock.

55 See for example $R v$ Panel on Take-overs and Mergers, ex parte Datafin plc [1987] QB 815 (CA); $R$ (Professional Counselling Aids Ltd) $v$ Code of Practice Committee of the Association of the British 
the unusual contexts: that is, jurisdictional barriers being replaced with more focused or restrained triggers for intervention and heightened contextualism. ${ }^{56}$ Further, as we see in the judgment itself, the Court could frame a method of supervision and legal benchmarks which respect the separation of powers and reserves intervention for the truly egregious.

We might, though, raise an eyebrow at the framing of the judicial task in terms of delineating the legal limits on the prerogative power, rather than an assessment of the propriety of its exercise. Fair cop. This was, I think, the judgment's biggest weakness: a cheeky, but perhaps understandable, attempt at smoke and mirrors. It is almost the reinvention of the awful jurisdictional error charade that still infiltrates Australian administrative law. ${ }^{57}$ And no one seriously believes the case turned on the Court dispassionately defining limits of power, agnostic to any assessment of the propriety of the exercise of power. Many, including me, would have preferred a more authentic discussion of the standard of review or basis for intervention. ${ }^{58}$ The decision is notable for not explicating any ground of review. Debate afterwards has continued: error of law, breach of constitutional principle, jurisdictional error, light-handed reasonableness, more intensive reasonableness, proportionality, or the dreadful innominate ground. ${ }^{59}$ We were left to read the tea leaves. All we know is that it was not an improper purpose, as the Court distanced itself from the employment of this ground by the Inner

Pharmaceutical Industry [1991] 3 Admin LR 697 (QB); and Poplar Housing and Regeneration Community Association Ltd v Donoghue [2001] EWCA Civ 595, [2002] QB 48.

56 See for example Bugdaycay v Secretary of State for the Home Department [1987] AC 514 (HL); Rv Ministry of Defence, ex parte Smith [1996] QB 517 (CA); Nottinghamshire County Council v Secretary of State for the Environment [1986] AC 240 (HL); $R v$ Secretary of State for the Environment, ex parte Hammersmith and Fulham London Borough Council [1991] 1 AC 521 (CA) at 597; Mercury Energy Ltd v Electricity Corporation of New Zealand Ltd [1994] 2 NZLR 385 (PC); $R$ (Cart) v Upper Tribunal [2010] EWCA Civ 859, [2011] QB 120; $R$ (Cart) v Upper Tribunal [2011] UKSC 28, [2012] 1 AC 663; and Pham v Secretary of State for the Home Department [2015] UKSC 19, [2015] 1 WLR 1591.

57 Craig v South Australia (1995) 184 CLR 163; Mark Aronson "Jurisdictional Error without the Tears" in Matthew Groves and HP Lee (eds) Australian Administrative Law (Cambridge University Press, Cambridge, 2007) 330; and Lisa Burton Crawford and Janina Boughey "The Centrality of Jurisdictional Error: Rationale and Consequences" (2019) 30 PLR 18.

58 Dean R Knight "Reasoning Through Challenges to Prorogation: Cherry and Miller (No 2)" (16 September 2019) UK Constitutional Law Association Blog 〈www.ukconstitutionallaw.org>.

59 See for example Mark Elliott "The Supreme Court's judgment in Cherry/Miller (No 2): A new approach to constitutional adjudication?" (24 September 2019) Public Law for Everyone <www.publiclaw foreveryone.com>; Roger Masterman and Se-shauna Wheatle "Miller/Cherry and Constitutional Principle" (14 October 2019) UK Constitutional Law Association Blog <www.ukconstitutionallaw.org>; Jefferi Hamzah Sendut "The Prorogation Case: Proportionality in All but Name?" (8 October 2019) UK Constitutional Law Association Blog <www.ukconstitutionallaw.org>; Amanda Sapienza "Miller 2 Jurisdictional Error Strikes Back" (7 October 2019) Administrative Law in the Common Law World <www.adminlawblog.org>; and Dean R Knight "Contextual review: the instinctive impulse and unstructured normativism in judicial review" (2020) 40 Legal Studies 1. 
House. ${ }^{60}$ What is clear, though, is that there are plenty of modifiers that seek to mark this case out from the workaday business of the supervisory courts. Note especially the use of the aggravating adjectives: "constitutional", "exceptional", "serious" and so forth. Seen in this way, the judgment does contain some hints of standards and methodological constraints.

Critics also worry about the relief granted and the narrow interpretation of proceeding in Parliament. ${ }^{61}$ Again, the criticism is that this must be wrong and will cause the sky to fall. The criticism tends to be a bald normative assertion of wrongness, rather than analysis or reference to lines of jurisprudence. Others point out that, again, the approach here is not out of step with other precedents looking at the meaning of "proceeding in Parliament", where its cloak does not immunise external activities. ${ }^{62}$ This argument is often reasoned from the quirk about the Parliamentary Buildings Bill purportedly being quashed, which is, in my view, a red herring, given its likely severability.

Forgive me for dashing through those criticisms in short order. They are, perhaps, mere debate points, which risk being irrelevant. I suspect folk will continue debating these points to the end of days. For what it is worth, I agree with those arguing Miller (No 2) is not doctrinally exceptional.

I think, though, entering the debate on these doctrinal points misreads the judgment - and misreads Miller (No 2) as a case about the judicial review of administrative action. ${ }^{63}$ It is not really about that. It is a constitutional judgment, rarefied in voice, institutional in concern. It is a decision focused on structural relationships within a constitutional ecosystem, rectifying relationships which have gone out of whack. We can see that in the gear shift it takes in its style of reasoning and overriding concern with constitutional principle and dynamics. We can see that in the way it speaks of how parliamentary accountability animates the relationship between the executive and Parliament. We can see that in the sketch of a democratic model of responsible government that lies at its heart. In other words, Miller (No 2) is the Supreme Court acting as a constitutional court, rather than a court supervising administrative decision-making. The line between administrative and constitutional law is not, of course, always stark. But, viewed in this light and with the lens of constitutional balance, it is hard to

60 Miller (No 2), above n 1, at [54].

61 See above n 53

62 Anne Twomey "Article 9 of the Bill of Rights 1688 and Its Application to Prorogation" (4 October 2019) UK Constitutional Law Association Blog <www.ukconstitutionallaw.org>; Anne Twomey Brexit, the Prerogative, the Courts and article 9 of the Bill of Rights (Commonwealth Parliamentary Lecture, Parliament House, Canberra, 28 November 2019); and Craig "The Supreme Court, prorogation and constitutional principle", above n 3 .

63 I do not suggest this is the only instance of the Supreme Court might be thought to have so shifted gears, but it is especially patent here. Miller (No 1), above $\mathrm{n} 52$, is an obvious another candidate too, along with decisions such as $R$ (Nicklinson) v Ministry of Justice [2014] UKSC 38, [2015] AC 657 and perhaps some judges' reasons in Re Human Rights Commission for Judicial Review (reference by the Court of Appeal (Northern Ireland)) [2018] UKSC 27, [2018] NI 228. 
quibble with the Court's correction. A strong nudge, to remind the executive that it governs in partnership with the people's assembly. The political constitution is fuelled by dynamic relationships between our political actors - tensions which generate checks and balances. But those relationships must be active and healthy relationships. The system would be compromised by allowing a selfrighteous executive to dominate, sideline or neuter Parliament. Hence, the constitutional recalibration that lies at the heart of Miller (No 2).

This change in voice - the shifting of judicial gears - also consigns many of the potential quibbles into the darkness. As mentioned earlier, the case goes out of its way to mark itself out as different: whether in terms of the exceptional circumstances, emphasis on the egregious or careful conditioning of the circumstantial. In my view, only a Supreme Court could issue a decision of this type and, then, only in remarkable circumstances. Those doomsayers - foretelling the floodgates opening to the judicialisation of the political and so forth - need not worry.

\section{VI}

What then does Miller (No 2) mean for us in New Zealand?

We can turn to our "what if?" Could a similar meltdown happen here? And, if so, how would our constitutional agents react?

Those questions invite us to grapple, once again, with our own creation story. The ebb and flow between importation and indigeneity. ${ }^{64}$ We naturally turn our eyes to the goings on at Westminster one of our constitutional tūpuna. We have imported, and continue to import, judicial review principles and doctrine from the Royal Courts of Justice on the Strand, a committee room in the Palace of Westminster and, now, the Middlesex Guildhall on Parliament Square. But our South Pacific nation also has distinctive characteristics, fuelled by a different societal context, some different design choices and different political experiences. Thus, the assessment of the implications of Miller (No 2) for New Zealand is a question with a degree of complexity. But, while still tentative and speculative, we can turn to prorogation and reflect on what we might expect from our organs of government. ${ }^{65}$

Could the executive shut down Parliament for an extended period?

There is a formal and substantive way of answering that question. In a formal sense, we have a prorogation power, now provided for in s 18(2) of the Constitution Act 1986. Like the United Kingdom, the executive may flick the switch on Parliament by so advising the Governor-General. It matters little, I think, it takes statutory form nowadays here.

64 Dean R Knight "Importation and Indigeneity" in TT Arvind and others (eds) Executive Decision-Making and the Courts: Revisiting the Origins of Modern Judicial Review (Hart Publishing, Oxford) (forthcoming).

65 For some other reflections on local implications see Edward Willis "The United Kingdom Supreme Court's judgment in Miller No 2" [2019] NZLJ 352. 
In a substantive sense, we need to reflect on the practice and politics of Parliament. It is notable that the idea of prorogation, in practice, has drifted into the shadows. Parliament has not been prorogued since 1991 and, then, only as a work around to recall Parliament while it was adjourned to consider the Iraq War. ${ }^{66}$ In the ordinary course, the view is there no need to prorogue our three year terms into session like in the past.

In practice, Parliament's business has evolved into sittings based around an annual pattern within an ongoing term. Crucially, the cross-party Business Committee - a body absent in Westminster takes responsibility for shaping the workings of Parliament. ${ }^{67}$ This committee decides matters on the basis of near unanimity. ${ }^{68}$ Thus, the practice, in reality, is that the programming of Parliament's business is not the sole prerogative of ministers, despite the formal vesting of power in the executive. Dissolution perhaps stands apart. But note the recently crystallised convention that the election date be announced early, ${ }^{69}$ along with the clear directive that, if confidence is lost, the caretaker convention applies and the unilateral right to dissolve disappears. ${ }^{70}$

Further, the nature of the executive-parliament relationship generally reinforces this partnership. There is a deep understanding that executive government in New Zealand nowadays must govern with and through Parliament. Many things have coloured that understanding. But two significant ones are worthy of particular mention. The first is Muldoon. ${ }^{71}$ Our judicial re-calibration, Fitzgerald $v$ Muldoon - where the prime minister was reminded he could not suspend laws without the consent of Parliament - has been canonised and is memorialised as the first case read by public law students throughout the country. ${ }^{72}$ It is not forgotten easily. The second is MMP, our mixed member proportional electoral system. ${ }^{73}$ Our move to a proportional electoral system destabilised the "elective dictatorship" - as we hoped - through the atomisation of political parties within Parliament and

66 Mary Wilson and David Wilson (eds) McGee: Parliamentary Practice in New Zealand (4th ed, Oratia Books, Auckland, 2017) at 143.

67 Standing Orders of the House of Representatives 2017, SO 77-82.

68 Standing Orders of the House of Representatives 2017, SO 78(1).

69 John Key "General Election to be held on 26 November" (press release, 2 February 2011); John Key "General Election to be on 20 September 2014" (press release, 11 March 2014); and Jacinda Ardern "PM announces election date as September 19" (press release, 28 January 2020).

70 Cabinet Office Cabinet Manual 2017 at [6.21]-[6.30].

71 For explanation see Geoffrey Palmer "Muldoon and the Constitution" in Margaret Clark (ed) Muldoon Revisited (Dunmore Press, Palmerston North, 2004) 167.

72 Fitzgerald v Muldoon [1976] 2 NZLR 615 (SC); and Stephen Kós "Constitutional collision: Fitzgerald v Muldoon v Wild" (2014) 13 Otago LR 243.

73 Matthew Palmer and Dean Knight Constitution of New Zealand (Hart Publishing, Oxford) (forthcoming). 
inevitable need for executive collaboration. ${ }^{74}$ Culturally, political agents accept the need to garner support for their policy initiatives through the people's assembly. Much, but not all, of the manifestos of government parties receives democratic blessing. Sometimes other parties may press things contrary to the wishes of ministers but the sky does not fall if the government's view does not prevail. It is also notable that functionally, the operating protocols of Cabinet and Parliament have been reshaped in numerous ways to entrench a collaborative executive-legislative dynamic. One oddity, which I think should be expunged, is the financial veto, which feels like a relic of yesteryear. ${ }^{75}$ Thus, our recent structural reform and recast traditions probably inoculate us from the excesses of executive power and righteousness that catalysed Miller (No 2).

If the unthinkable did happen, though, how would the other constitutional figures react? We turn first to the Head of State. Remember, the British tradition is that the Queen herself - the person blessed with wearing the Crown - lacks any agency. Full stop. Despite theoretical possibilities, she would never step in. Oddly, some of the thinking is that a Governor-General - a more bureaucratic delegate - might have fractionally more wriggle room and soft power than the principal. ${ }^{76}$ To be clear, deviation from the cardinal constitutional convention that the Governor-General acts on the advice of her responsible advisors is, for good reason, never lightly contemplated. But consider two points. First, at the time Johnson advised prorogation, the numbers in Parliament were murky, and there was some uncertainty about whether, as a matter of objective quantity, he commanded confidence of the Commons. Our New Zealand system sets the Governor-General up as the sentinel of confidence perhaps flipping the traditional understanding of confidence in negative terms into an essential condition to tender advice. ${ }^{77}$ It is teamed with a strong caretaker convention, throttling back the power of government if it lacks confidence. Might our Governor-General have invited the Prime Minister to clarify the position on confidence before agreeing to the exercise of the dramatic power to prorogue? Soft power only, to seek clarification of the numbers. Perhaps? Maybe? Certainly, a calculus based on objective numbers insulates a Governor-General somewhat.

Secondly, albeit trickier, is the idea of Governors-General as ultimate guardians of constitutionality. Some speculate that constitutionally egregious advice, especially that which seriously undermines the core operation of responsible and representative government, may be

74 Palmer, above n 71, at 169.

75 Standing Orders of the House of Representatives 2017, SO 326.

76 Anne Twomey The Veiled Sceptre: Reserve Powers of Heads of State in Westminster Systems (Cambridge University Press, Cambridge, 2018) at ch 2; and Anne Twomey "From Bagehot to Brexit: The Monarch's Rights to be Consulted, to Encourage and to Warn" (2018) 107 The Roundtable 417.

77 Palmer and Knight, above n 73; and Twomey The Veiled Sceptre, above n 76, at 292. For an instance where the Governor-General closely scrutinised the position on confidence during midterm resettlement of government, absent any no confidence trigger: see Michael Hardie Boys The Constitutional Challenges of MMP: A Magical Demystification Tour (Institute of Policy Studies, Paper No 1, 1999). 
refused. ${ }^{78}$ Does that sound familiar? Others, like Quentin-Baxter and McLean, suggest this potential guardianship has never been realised in New Zealand and is a pipe-dream. ${ }^{79}$ Even if Miller (No 2) outlines a touchstone of egregious unconstitutionality that could, in principle, provide a degree of symmetry for constitutional guardians, I worry any such judgement may still be too radioactive for our bureaucratic Governors-General. And I say that even though one of their Canadian counterparts is understood to have approached a similar question as a matter of vice-regal discretion, albeit ultimately acceding to advice. ${ }^{80}$ Leaving constitutional validity to the courts probably remains the most likely course here. ${ }^{81}$

What then of our courts? Would they write a judgment like Miller (No 2)? If we think of the scenario in judicial review terms, our courts' attitude to the prerogative, justiciability and institutional comity is probably less precious. Think about the approach to the review of the prerogative of mercy in Burt v Governor-General, perhaps the review of non-statutory Cabinet decision-making in Pora v Attorney-General, or Ngāti Whātua Ōrākei Trust v Attorney-General on justiciability in the context of Te Tiriti o Waitangi settlement legislation. ${ }^{82}$

The deeper question might be whether our Supreme Court judges see themselves as a constitutional court. Could they have shifted gears and adopted a constitutional voice like their British counterpart? I think the jury is still out on that one. For example, the recent Taylor cases - where there seemed to be a similar opportunity - were decidedly doctrinal and constitutionally underwhelming. ${ }^{83}$ We might need to track back to the New Zealand Maori Council cases in the 1980s and 1990s to find that gutsy, and unashamedly constitutional, vibe. ${ }^{84}$ Perhaps Baigent's case might be another. ${ }^{85}$ To be

78 Philip A Joseph Constitutional and Administrative Law in New Zealand (4th ed, Brookers Ltd, Wellington, 2014) at 730 and 742; and Twomey The Veiled Sceptre, above n 76, at ch 10.

79 Alison Quentin-Baxter and Janet McLean This Realm of New Zealand: The Sovereign, The GovernorGeneral, The Crown (Auckland University Press, Auckland, 2017) at ch 10.

80 Twomey Veiled Sceptre, above n 76, at 598; and Peter H Russell and Lorne Sossin (eds) Parliamentary Democracy in Crisis (University of Toronto Press, Toronto, 2009).

81 See Joseph's explanation of reserve powers as "recourse of last resort": Joseph, above n 78, at 743.

82 Burt v Governor-General [1992] 3 NZLR 672 (CA); Pora v Attorney-General [2017] NZHC 2081, [2017] 3 NZLR 683; and Ngāti Whātua Ōrākei Trust v Attorney-General [2018] NZSC 84, [2019] 1 NZLR 116.

83 Attorney-General v Taylor [2018] NZSC 104, [2019] 1 NZLR 213; and Ngaronoa v Attorney-General [2018] NZSC 123, [2019] 1 NZLR 289.

84 New Zealand Maori Council v Attorney-General [1987] 1 NZLR 641 (CA); Attorney-General v New Zealand Maori Council [1991] 2 NZLR 129 (CA); and New Zealand Maori Council v Attorney-General [1996] 3 NZLR 140 (CA).

85 Simpson v Attorney-General [1994] 3 NZLR 667 (CA) [Baigent's case]. 
fair, the Supreme Court might be in a period of transition and more might be expected in upcoming phases. Something to watch.

\section{VII}

Those are some musings on the Miller (No 2) saga. It stands as an extraordinary time in British political history, with heightened tensions between the executive and Parliament - and, subsequently, the courts. Parliament's central role in Westminster was reemphasised and the notion of parliamentary accountability was given amplified status. There is much more that could be explored, including the wisdom of fixed-term parliaments, what Miller (No 2) tells us about the virtues of written constitutions, the nature of confidence in the Westminster system, and the erosion of conventions and civic virtue. But they are bowls of popcorn for another day. 